\title{
INVESTIGACION
}

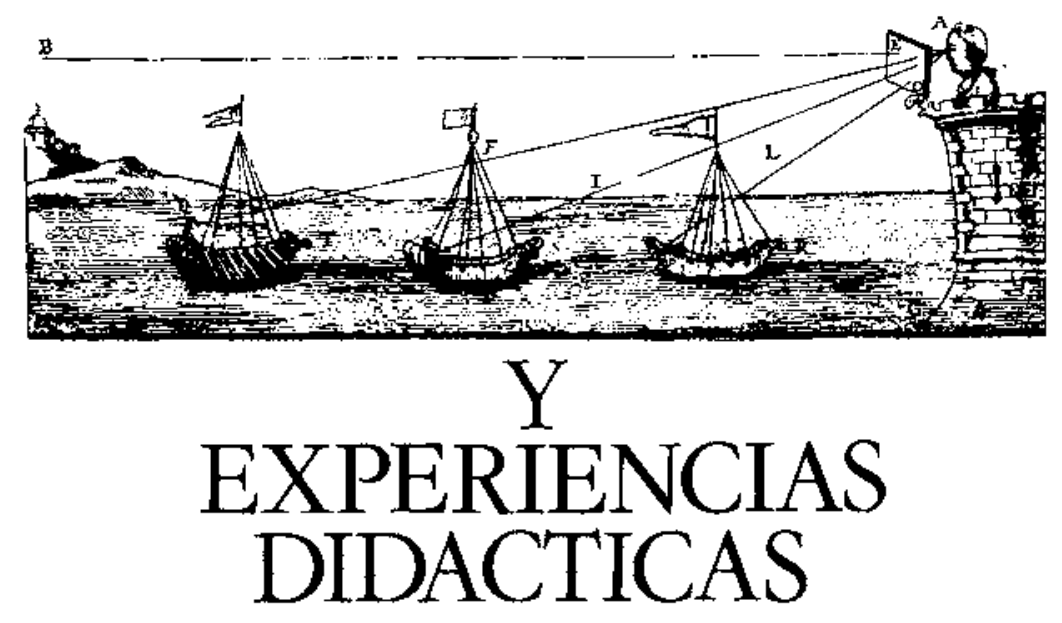

\section{VARIETIES OF SCIENCE EDUCATION RESEARCH: THEIR APPLICATIONS IN THE CLASSROOM}

\author{
LUCAS, A.M. \\ Centre for Educational Studies. King's College. University of London. London.
}

\section{SUMMARY}

To aid in the task of demonstrating that a variety of research questions needs to be addressed, this paper gives a sketch of the functions of modern science education, then uses that sketch to identify topics about which we need research data, and suggests possible implications for practice.

\section{INTRODUCTION}

It is easy to be seduced by fashionable areas of research and to think that the results of that work must be the most important ideas to incorporate into the classrooms. There is no doubt that the fashionable science education work in the past decade, especially in Europe, Australia and New Zealand, has been in the area of "alternative frameworks', investigating the variety of ideas that learners have about physical and biological phenomena. We 
now know a great deal about the range of ideas that learners have about energy, light, electricity, photosynthesis, inheritance, force and motion, and the particulate nature of matter. (See for reviews and summaries, Driver, Guesne \& Tiberghein 1985, Osborne \& Freyberg 1985). More and more research on these and other topics is being published, and there are some published sche. mes for incorporating these ideas into classroom activities (Children's Learning in Science 1987). Most teachers of science who read the journals addressed to the classroom teacher must have seen at least some discussion of these results and their implications for the classroom. The work has been so influential that the new science curriculum proposals in both Spain and England and Wales contain explicit references to pupil learning that owe much to the views underlying the "alternative framewor * ks' research (See National Curriculum Council, 1989, p. A7, and [Spanish MEC] 1989, p. 111).

In this paper I will try to counteract an over-emphasis on that area of research.

Do not misunderstand me: I do believe that research on 'spontaneous reasoning', 'alternative frameworks' or 'children's explanations' is valid and important. This fashionable area has given us a spate of very interesting papers that have shown science education researchers that the assumptions of the anglophone curriculum development projects of the 1960's were too simplistic. It is now clear that investing a great deal of money, time and expertise in the development of learning activities is not sufficient, unless these leaming activities take into account the way that pupils give meaning to the concepts that are 'obvious' to the teacher and curriculum developer. 'Alternative perceptions' research has also been of value to classroom teachers who, if they have read it sensitively, can never again take for granted the possibiIity that all children will share the same views after exposure to the teacher's version of phenomena. For some teachers, this research has legitimated their professional experience, confirming that the ideas that they have seen some pupils express are common; that it is not just their own teaching that produces these 'aberrations'.

To aid in my task of demonstrating that a variety of research questions needs to be addressed, I will sketch the functions of modern science education, then use that sketch to identify topics about which 1 believe we need research data, and suggest possible implications for practice.

\section{CONCERNS OF SCIENCE EDUCATION}

At a time of major education renovation in many countries, including both Spain and England and Wales, the purpose and value of science education is being addressed by the teaching profession, academic educators, scientists, and politicians. What place does science have in the community? What place does science have in the curriculum of schools?
The important point about intense re-examinations of the place of science education is not just that changes result from them, but that the questions are being asked. It is essential that they be asked, because as societies change, as social assumptions change, as science itself changes, then new answers emerge to the questions 'why teach science?', 'what science should we teach?', 'how can we teach that science most effectively?' Unless we have periodic re-examinations of the place of science in the school curriculum, then we may justly be accused of perpetuating the 'Sabre Tooth Curriculum', [insert reference] valuing the schooling that was relevant at the time the curriculum was created, but valuing it merely because of tradition.

One consequence of re-evaluating the basic purposes of science education is that new needs may arise, and that new combinations of needs may create new classroom conditions. 'Best methods' for the old patterns may no longer be appropriate or adequate. Peter Fensham (1988) points out that the curriculum developments of the 1960's in the United States and Britain were intended to induct the relatively able pupils into the world of science for political, economic and subject maintenance reasons. He argues that present trends include more emphasis being given to cultural, social and individual purposes of a science education, and the emphasis is more on learning from science. Roberts (1988) takes this analysis further and argues that every science curriculum, unique in time and place, results from negotiation between different curriculum emphases held by different 'stakeholders': parents, teachers, politicians, officials, employers, and perhaps pupils. Such negotiations will usually produce different curricula at different times. If Fensham and Roberts are correct, then we cannot expect research directed towards those old purposes to be sufficient to guide teachers meeting the new aims, the new populations, and the new curriculum of the present and immediate future.

In this paper, I use mainly the new requirements for science education in England and Wales (United Kingdom, Department of Education and Science 1989, National Curriculum Council 1989) as a starting point. Similar analyses can be done for the science proposals for 'La Reforma' in Spain, and the general conclusions that will emerge will be similar in principal, although they may differ in detail. For my purposes the English and Welsh requirements are more suitable: they are now in their final form, after being changed as a result of a three-stage consultation process; the requirements are presented in a more prescriptive way than in the Spanish consultative version; and the intended inter-relationships between various aspects are much more prescriptive.

\section{SCIENCE CURRICULUM DEMANDS}

\section{Basic scientific concepts}

There will always be a need to teach basic scientific concepts, even if the balance between the aims of scien- 
ce courses change. The criteria for selection of the concepts may change, the depth to which they must be taught may vary, and the desired interaction between the various concepts may differ, but science concepts will always be included in science courses. Thus in these areas there will always be a need for research that informs us how pupils cope with and make sense of the concepts being tatight. But the present balance within science courses requires us to consider more than 'content' aims represented by such statements as 'Pupils should know that when sound waves travel from one point to another they transfer energy through the medium' (United Kingdom, Department of Education and Science 1989 , p. 30), or 'Aspectos energéticos de la corriente eléctrica: función del generador y efecto calorífico de la corriente eléctrica' (MEC 1989, p. 153).

\section{Beyond scientific concepts}

The new science curriculum in England and Wales is defined in terms of 17 'Attainment Targets', with up to 10 levels in each. Examples of some attainment targets and associated levels are given in the appendix. It is intended that levels $1-3$ be appropriate for pupils aged 57 ; levels $2-5$ for pupils aged $8-11 ; 3-7$ for pupils $12+14$; 4-10 for pupils 15-16. Note that some assumptions about pupils' abilities are built into the legal specification: it is assumed that pupils will vary in their ability to achieve specified levels, and also that the range of achievement is greater in older pupils.

Table I

Content of National Cutriculum Science, for ages 5-16 in England and Wales.

\section{Attainment}

Target Number

Title

AT1
AT2*
AT3
AT4
AT5*
AT6
AT7*
AT8
AT9
AT10
AT11
AT12*
AT13
AT14
AT15*
AT16*
AT17*

Exploration of science

The variety of life

Processes of life

Genetics and evolution

Human influences on the Earth

Types and uses of materials

Making new materials

Explaining how materials behave

Earth and atmosphere

Forces

Electricity and magnetism

The scientific aspects of

information technology including electronics Energy

Sotund and music

Using light and electromagnetic radiation

The Earth in space

The nature of science

Attainment Targets marked * are not included in the "Model B' program that may be offered at ages 15 and 16 . It is expected that this shorter programme will be only offered to able pupils, who wish to concentrate on languages, for example.
Table 1 shows that the attainment targets include many familiar topic areas, but also that 'Exploration of Science' and the 'Nature of Science' must be taught. It is now a requirement to help pupiIs deveiop the intellectual and practical skills that allow them to explore the world of science and to develop a fuller understanding of scienti* fic phenomena and the procedures of scientific exploration and investigation. The activities should encourage the ability to:

i Plan, hypothesize and predict

ii Design and carry out investigations

iii Interpret results and findings

iv Draw inferences

v Communicate exploratory tasks and experiments.

(Attainment Target 1: 'Exploration of science', DES 1989: 3).

[The statement of the equivalent Spanish position is spread throughout the proposal, but similar ideas can be extracted from explicit comments made under the heading 'Procedimientos' in many of the content blocks, as well as the elaboration in sections $42-49$, pp. 179-183, and from the statement under 'Objectivos Generales' ( $p$. 119):

Desarrollar y aplicar estrategias personales en la resolución de problemas y en la exploración de situaciones y fenómenos desconocidos utlizando las estrategias y pautas de acción propias de la investi. gación científica de la realidad (identificar el problema, analizar sus elementos pricipales, recabar la información disponible, formular hipótesis plausibies para solitcionarlo, recoger datos relevantes para contrastar las hipótesis formuladas, analizar los datos de forma apropiada, formular conclusiones, explorar soluciones alternativas, etc.)]

Attainment Target 17 ('The nature of Science') contains content that has not been common in standard English science courses:

Pupils should develop their knowledge and understanding of the ways in which scientific ideas change through time and how the nature of these ideas and the uses to which they are put are affected by the social, moral, spiritual and cultural contexts in which they are developed; in doing so, they should begin to recognize that while science is an important way of thinking about experience, it is not the only way. (DES 1989, p. 36)

The two English statements show that the fashionable research area of alternative frameworks does not provide evidence on all areas that will concern classroom teachers. Attainment targets 1 and 17 do not involve phenomena that can be addressed by scientific procedures. The second also involves value judgements, and at a mature level in the school will require pupils to think about the differences between historical and scientific 
evidence, and may also involve them in moral and ethical debate.

\section{Science education as a vehicle for teaching general skills}

Teachers in England and Wales have been told that 'learning in science contributes to personal development':

Throughout their science education pupils should be encouraged to develop their powers of reasoning by reflecting on their own understanding, by reflecting and thinking about evidence in a disciplined way, and by appreciating that learning may involve changes in the way they think about, explain and do things. In this way science helps pupils to become independent learners. (National Curriculum Council 1989, p. A5)

This is not an aim unique to science education, but it is a strong part of the justification for teaching science.

Similarly, it is asserted that:

...scientific methods are usefully applied to enquiry in many contexts, for example in design and technology. Work in these areas will benefit directly from the increased relevance and inspiration that the application of scientific skills and strategies will bring. (National Curriculum Council 1989, p. A5)

Yet this claim is contrary to the experience of many teachers and researchers that skills and knowledge are often not transferred from the context of learning to a context of use.

\section{INSTRUCTIONAL DEMANDS}

The three areas outlined above are concerned with the aims of science education in the English and Welst National Curriculum for science. The aims are, at least theoreticaliy, independent of the methods teachers choose to use to teach them. But there is a great variety of teaching methods available to teachers, ranging from the didactic presentation of concepts, to the use of open ended investigations where the pupils and the teachers may not have a clear end point in mind, but where the procedures used in reaching a solution are the important teaching goals.

There has been in the past a great deal of research into classroom processes, examining the interaction between variables such as teacher styles, pupil personality and cognitive preferences, when different educational outcomes were considered. General research on such 'Aptitude-Treatment Interactions' in classrooms is reviewed briefly by Tobias (1976). Results from science classrooms show that there is a serious probiem for teachers who attempt to incorporate the results of the studies into classroom teaching: you cannot meet the needs of all of the pupils all of the time for all objectives. For example, Theobald (1977) showed that for memory of biological principles, class-centred teaching is better for students who are both 'open-minded' and have a 'cognitive preference for rote learning', white individual centred teaching is better for 'dogmatic' students and for those with a 'cognitive preference for principles' (Theobald's summary is quoted in Lucas 1986, p. 193).

Table II

Classroom concems and research areas

Aims Examples ___ Research areas

Curriculuro Issues

Science Concepts

force respiration chemical bonds erosion

Science Processes

controlling variables observing experimenting measurement microscopy

Science Applications design \& technology environmental issues probicm solving

Science and Society

effects on society effects of society historical context philosophic context

Science contributing to attitude development personal development personal hygiene reflect on thinking cognitive skills

experimental studies intervention studies descriptive accounts metacognition studies

Instructional Issues

Classroom processes

teacher styles classroom climate

ATI studies observational studies open-ended work intervention studies

New tools microcomputers information technology observation studies evaluation studics

Other areas of research dealing with classroom procedures and science education have been summarized by Fraser (1986), and there is an increasing need for research into the effects of using new instructional stran tegies, such as manipulating micro-computer modelbuilding systems (e.g., Wong 1987a, 1987b), data analysis packages (e.g., McCormick \& Squires 1988) internationally shared collection of data on environmental themes (e.g., National Environmental Database Project 1989), the effect of language structures on textbook usage (e.g., Kulkarni 1988), the uses of group work, and investiga* tive laboratory classes (Millar 1987).

Table 2 summarizes the areas of concern and includes an account of the type of research that is required to unders- 
tand each of the areas of concern. There are, of course many research studies that contain more than one style of research within and between areas of concern. The table does not mean that the research studies must be discrete, directed to only one area of concern, and based on single methodologies. Some of the best studies are long term (although there are few of them, see Arzi 1988), and concern themselves with a variety of issues. The report of the Assessment of Performance Unit on the studies of science at age 13 in England and Wales (Schofield et al. 1989) looks at many of the areas of concern in the table, and relates, as far as possible in the survey design, a number of analyses. For example, the report considers pupil's interests and perceptions relating to science, their use of graphical and symbolic representations, their observation skills, their application of science concepts to novel situations, and the planning and performance of investigations. Even this extensive and expensive study, however, does not look at all issues of current concern: there is no assessment of concepts related to the interaction of science and society, nor of an historical awareness.

\section{APPLICATION TO THE CLASSROOM}

\section{How should the teacher approach classroom science?}

The simplest answer to the question is both the most helpful and the most obscure: the teacher needs to teach so that the aims of the total science curriculum are taken into account in every lesson.

It is the most helpful answer because it emphasises the need to be integrative; to avoid focussing only on the fashion of the moment. When we look at the incorporation of ideas from the alternative conception movement, do we stop to consider whether implementing the recommendations of the curriculum planners who have been influence by these ideas will inhibit or enhance the achievement of the wider aims? What message about the nature of science will be gained, perhaps unconsciously, by the pupils who follow the method of explication of their existing ideas, followed by confronting these ideas with phenomena? (Driver 1989, p. 88 for a diagrammatic schema of this mode of teaching.) What will it tell the pupil about the historical status of scientific ideas? Will it enable the pupil to have more than a simplistic idea of the relationship between data and interpretation? Between hypothesis and research design? Between identification of variables and the type of investigation undertaken? (Lucas \& Tobin 1987). Between conceptual framework, received wisdom, and the interpretation of simple classroom exercises? (Lucas \& García-Rodeja Gayoso 1989). In addition, focusing solely on the results of the 'alternative conception' movement will reinforce the risk of 'talking about pupils learning science as if they were science learning machines, devoid of feelings and other demands on their attention' (Head 1989:153).

The answer is most obscure because it tells us little of how to integrate the findings of the extensive alternative conceptions work with the comparatively small amounts of actual classroom research on how pupils approach the tasks of identification of variables and the design of experiments ( Schofield et al. 1989, for some discussion of this area), and the extremely limited research into pupils' skills in interpreting change in scientific ideas in an historical context. Most of the literature in the latter area is analytic, comparing textbook accounts with historical studies, usually showing that the textbook histories are, at best, limited, and at worst, seriously distorted, accounts of the development of scientific ideas (Brush 1974, Arons 1988, Root-Bernstein 1989).

In the absence of good syntheses of recent research in areas other than classroom climates and the alternative conceptions movements we are forced to use general principles, and argue from our 'professional judgement'. This is not necessarily a major limitation, because the act of so arguing can raise questions for research.

Perhaps the most important message is to look to the theoretical underpinings of the research, if possible some synthesis of theoretical perspectives. Critics (e.g. Claxton 1989) have argued that the interpretation of 'constructivism' implicit in the work of many of the current science education researchers is too narrow, and others suggest that it is under-theorized. For example, the pattern of lessons suggested by Driver (1989) may not work equally well for all types of science concepts. I suspect that the technique will work well for those topics where pupils can directly confront phenomena (is it an accident that the examples used in Driver (1989) are those that appear to be modifying generalizations that are based relatively directly on observation of phenomena?), but that it will not be so successful in inducting pupils into explanatory theories. Rowell and Dawson (1989) distinguish between concepts of the first type, such as Archimedes Principle, which they refer to as 'inductive generalizations', and concepts of the second type, which they call 'constructive generalizations', such as the kinetic theory of gases, which require a change in knowledge frameworks either by revising theories or creating new ones. (Note that Rowell and Dawson have arrived at their position by a synthesis of Piagetian developmental theories, cognitive process psychology, and aspects of theories of artificial intelligence.)

Theoretical underpinnings for the other areas of concern are less secure. We can turn to arguments from developmental psychology for some guidance about the possible levels of sophistication that pupils can reach in the interpretation of scientific processes, such as hypothesizing, drawing inferences, and handling variables, although it is important here to note that recent work by Adey and Shayer has demonstrated that it is possible to train pupils in the formal operational skills of control and exclusion of variables, ratio and proportionality, etc., so that their achievement of these indicators of Piagetian formal thinking is accelerated compared to untreated groups. (Adey, Shayer \& Yates 1989, for a preliminary report of the study). We know that the context of testing and instruction makes a great difference in pupils apparent abilities to design experiments (Murphy 1989), but a theoretical explanation of the 
complex patterns achieved is lacking, and in the absence of an adequate theory it is difficult to generalize to classroom contexts.

To sum up, I believe that we need to develop a pedagogy that is sensitive to the complex demands of science classrooms that are trying to meet multiple aims. I believe we can do this, by selecting investigations to use in the classroom that will force the pupil to confront evidence (similar to the strategies devised by the CLIS group in Leeds), but which pay due attention to the validity of the interpretations made of the data collected (Lucas \& García-Rodeja Gayoso). A judicious use of classical experiments interpreted with proper historiography (Arons), and which reflects defensible philosophic models of science, will help give adequate attention to the historical dimensions.

To handle these demands, teachers need to be both sensitive to the history and philosophy of science, and aware of the methods of ensuring that pupils are aware of the differences between scientific and other types of argument. They also need text books that meet this challenge.

A family of techniques that seem to be able to incorporate most of these aims is being developed around the world. These techniques which have a variety of local variants, are collectively known as 'meta-cognitive strategies', and have in common an emphasis on helping pupils become aware of their own learning. For accounts with an emphasis on science education applications see Novak (1989), and Baird (1986).

\section{Methods of helping teachers meet these goals?}

The most important problem remains to be addressed. How do we incorporate the results of research in science education into classroom practice?

As White (1988) points out, most programmes of reform based on theories of instruction have not had a great impact on classrooms. He suggests that the lack of success is because of the isolation of teachers, "practical problems of school organization', and the ambivalent view of academics held by practising school teachers. He comments that 'theory cannot be launched into practice like a missile: rather it has to be cultured and nurtured Iike a plant' (p. 130). In the project that he uses to illustrate his argument, 10 teachers in one Australian school made a determined effort to develop a metacognitive teaching strategy. The Project for Enhancing Effective Learning (PEEL) aimed to

improve the quality of school learning and teaching. Training for this improvement is centred on having students become more willing and able to accept responsibility and control for their own learning. Training has three aspects: increasing students' knowledge of what learning is and how it works; enhancing students' awareness of learning process and outcome; improving students' control; of learning through more purposeful decision-making. (Baird \& Mitchell 1986)
(Further details about the metacognitive strategies involved can be found in Baird 1986).

As a result of this experience White argues that it is essential that the costs to teachers of an innovation are recognized: teachers abandoning well tried techniques put themselves back into the position of teachers just starting their carer, and have to take the risk of living with the consequences of failure. He attributes the apparent success of PEEL to the presence of two important linking groups, (i) former teachers who have become psychologists, and (ii) active teacher-researchers.

The PEEL context is an unusual one. It does not represent the normal division and flow of research information, where the researcher carries out the work, reports it in a research journal, and, with Iuck, in a journal addressed to teachers. The teacher may try to introduce the ideas into the classroom, but will often fail, for good reasons. The support available may be limited; the theoretical underpinnings that are obvious to the researcher may not be sufficiently clearly described for the teacher to adapt the description of the procedure to the specific circumstances of the school; the pressures exerted by pupils and other staff to conform to the traditional roles may be too strong for the teacher to resist (for examples of pressures applied by pupils see Lucas 1980, p. 168, Mitcheil 1986 , pp. 50-52); performance on test scores often goes down when teachers begin to use completely new strategies and they may abandon the strategy too early (Novak 1989, in commentary, p. 239).

How then are researchers and those responsible for inservice education to influence practice by encouraging teachers to use methods and techniques that are based on research studies?

Unfortunately, there is no simple answer to this problem. Much of what we do in inservice work is based on 'professional judgement' rather than on tested and researched approaches to inservice work, and we know that our assumptions are open to question. For example, sometimes projects for curriculum innovation use teachers as the developers/implementers, in the hope that this will remove the gap between academic and teacher, with the academics acting as consultants on technical issues. But the use of teachers is no guarantee that barriers to innovation found in many studies of $\mathrm{cu}$ rriculum diffusion will be bridged. Simon (1989), has shown that many of the problems of communication of intent that occurred in the Graded Assessment of Science Project (GASP) (Swain 1988) had been demonstrated in previous studies of innovation, including some carried out within the department where GASP was located!

Other studies have found that major change in the classroom can be initiated when the teachers work closely with researchers (Adey, Shayer \& Yates 1989, Treagust, Leggett, Glasson \& Wilkinson 1989), but these are expensive methods of initiating change. In the Treagust et al, case, three researchers were closely involved with one teacher! What we need to do is to establish better methods of wide-spread dissemination of ideas, methods that allow the teacher to retain many of the advan- 
tages of working closely with an outsider who helps him to become a 'reflective practitioner' (Schon 1983).

I suspect that what will be needed is the development of clusters of schools, where teachers support each other, by visiting each other's classrooms, by critically obser* ving the way in which pupils are working and thinking.

\section{REFERENCES}

ADEY, P., SHAYER, M. and YATES, C., 1989. Cognitive acceleration: the effects of two years of intervention in science classes, in Adey, P. (ed.), Adolescent development and school science. (Falmer, pp, 240-248).

ARONS, A. B., 1988. Historical and philosophical perspectives attainable in introductory physics courses, Educational Philosophy and Theory, 20(2), pp. 13-23.

ARZI, H., 1988. From short- to long-term: studying science education longitudinally, Studies in Science Education, 15 , pp. 17-53.

BAIRD, J. R., 1986. Improving learning through enhanced metacognition; aclassroom study, European Journal of Science Education, 8, pp. 263-282.

BAIRD, J.R. and MITCHELL, 1. J., 1986. Improving the quality of teaching and learning: An Australian case study-the PEEL project. (Monash University).

BRUSH, S. G., 1974. Should the history of science be rated $X$ ?, Science, 183, pp. 1164-1172.

Childrens Learning in Science, 1987. CLIS in the classroom: Approaches to teaching. Centre for Studies in Science and Mathematics Education, University of Leeds.

CLAXTON, G., 1989. Cognition doesn't matter if you're scared, depressed or bored, en Adey, P. (ed.), Adolescent development and school science. (Falmer, pp. 155-161).

DRIVER, R., 1989. Changing conceptions, en Adey, P. (ed.), Adolescent development and school science. (Falmer, pp.79103).

DRIVER, R., GUESNE, E. and TIBERGHEIN, A., 1985. Children's ideas in science. (Open University Press).

FENSHAM, P. J., I 968. Familiar but different: some dilemmas and new directions in science education, en Fensham, P. J. (ed.), Development and dilemmas in science education. (Falmer Press, pp. 1-26).

FRASER, B. J., 1986. Classroom environment. (Croom Heim).

HEAD, J., 1989. Beyond the cognitive, en Adey, P. (ed.), Adolescent development and school science. (Falmer, pp. 153154).
That is, teachers should focus on the transactions in the classrooms, and not merely the results of the teaching. The existence of such clusters will help to overcome the main problem of inservice courses: the single injection of ideas, without continued support while these are being developed and extended to a variety of science concepts in a variety of school contexts.
KULKARNI, V. G, 1988, Role of language in science education, en Fensham, P. J. (ed.), Development and dilemmas in science education. (Falmer Press, pp. 160-168).

LUCAS, A M., 1980. The development of a curticulum monopoly in Australian secondary schools: Biological Science: The Web of Life. 2. Research and comment, Journal of Biological Education, 14, pp. 167-174.

LUCAS, A M., 1986. Tendencias en la investigacion sobre la enseñanza /aprendizaje de la biología, Enseñanza de las Ciencias, 4(3), pp. $189 \cdot 198$.

LUCAS, A. M. and GARCÍA-RODEIA GAYOSO, I., 1989. Contra las interpretaciones simplistas de los resultados de los experimentos realizados en el aula, Enseñanza de las Ciencias.

LUCAS, A. M. and TOBIN, K., 1987. Problems with "control of variables' as a process skill, Science Education, 71 , pp. 685-690.

MCCORMICK, S. and SQUIRES, D., Three dimensional analysis of biological data: issues relating to software design in Windows, en Lovis, F. \& Tagg, E. D., (eds.), Computers in Education. (Elsevier Science Publishers, pp. 605-610).

MEC, 1989. El diseño curricular base. Área de Ciencias Experimentales. (MEC: Madrid).

MITCHELL, I. J., 1986, en Baird, J. R., \& Mitchell, I. J., 1986. Improving the quality of teaching and learning: An Australian case study-the PEEL project. (Monash University, pp. 45-85).

National Curriculum Council, 1989. Science: Non-statutory guidance. NCC.

National Environmental Database Project, 1989. Phase Il trial: Acid Rain pack. (Centre for Educational Studies, King's College London).

NOVAK, J., 1989. The use of metacognitive tools to facilitate meaningful learning, en Adey, P. (ed.), Adolescent development and school science. (Falmer, pp. 225-239).

OSBORNE, R. and FREYBERG, P., 1985, Learning in Science: The implications of children's science. (Heinemann). 
ROBERTS, D. A., 1988. What counts as science education?, en Fensham, P. J., (ed.), Development and dilemmas in science education. (Falmer Press, pp. 27-54).

ROOT-BERNSTEIN, R. S., 1989. How scientists really think, Perspectives in Biology and Medicine, 32, pp. 472-488.

ROWELL, J. A. and DAWSON, C. J., 1989. Towards an integrated theory and practice for science teaching, Studies in Science Education, 16, pp. 47-73.

SCHOFIELD, B., BELL, J., BLACK, P., JOHNSON, S, MURPHY, P., QUALTER, A. and RUSSELL, T., 1989. Science at age 13: A review of $A P U$ Survey findings $1980-84$. Assessment of Performance Unit, Department of Education and Science. (Her Majesty's Stationery Office).

SCHON, D., 1983. The reflective practitoner. Basic Books.

SIMON, S., 1989. Curriculum and assessment innovation in science: a study of the introduction of the Graded Assessments in Science Project in two schools. Unpublished PhD dissertation, King's College London, University of London.
SWAIN, J. R. L., 1988. GASP: the Graded Assessments in Science Project, School Science Review, 70, pp. 152-158.

TOBIAS, S., 1976. Achievement treatment interactions, Review of Educational Research, 46, pp. 61-74.

TREAGUST, D., LEGGETT, M., GLASSON, P. and WILKINSON, B., 1989. Enhancing the teaching of physics through teacher-researcher interactions, Australian Science Teachers Journal, 35(1), pp. 75-81.

United Kingdom, Department of Education and Science, 1989. Science in the National Curriculum. (Her Majesty's Stationary Office).

WHITE, R. T, 1988. Theory into Practice I, en Fensham, P. J. (ed.), Development and dilemmas in science education. (Falmer Press, pp. 121-132).

WONG, D., 1987a. Teaching A-level physics through microcomputer dynamic modeiling: I Teaching methods, Journal of Computer Assisted Learning, 3, pp. 41-52.

WONG, D. $1987 \mathrm{~b}$. Teaching A-level physics through microcomputer dynamic modelling: II Evaluation of teaching, Journal of Computer Assisted Learning, 3, pp. 164-157. 


\section{APPENDIX}

\section{Two examples of Atainment Targets in National Curriculum for Science in England and Wales}

In these examples, the words printed in italics are examples, and do not have statutory force.

\section{Attainment Target 15}

Using light and electromagnetic radiation

Pupils should develop their knowledge and understanding of the properties and behaviour of light and electromagnetic waves.

\section{Level Statements of Attainment}

Pupils should:

1 Know that light comes from different sources.

$\mathrm{Be}$ able to discriminate between colours and match them or, where appropriate, demonstrate an understanding of colour in the environment.

2 Know that light passes through some materials and not others, and that when it does not, shadows may be formed.

Be able to draw pictures, showing features such as light, colour and shade.

3 Know that light can be made to change direction and shiny surfaces can form images.

Be able to give an account of an investigation with mirrors.

4 Know that we see objects because light is scatered off them and into our eyes.

Know that light travels in straight lines and use this to explain the shapes and sizes of shadows.

5 Understand how light is reflected.

6 Understand how prisms and lenses refract and disperse light.

$\mathrm{Be}$ able to give an account of the structure and function of the eye.

Understand the principles of the common defects of sight and their correction.

7 Be able to describe and use the wave model of the nature of electromagnetic radiation.

Know that there are many types of radioactive radiation, that they are important in everyday life, and be able to describe some of their applications.

Be able to explain how some optical devices work, for example, simple camera, projector and optical fibre.

8 Understand refraction as an effect of differences of velocities in different media.

9 Know that the electromagnetic spectrum forms a continuum of radiation with different physiological effects.

Be able to select, summarize and present information conceming the application of electromagnetic waves in domestic contexts, communication and medicine.

Understand the processes of dispersion, interference, diffraction and polarisation of light. 


\section{Attainment target 17:}

The nature of science

Pupits should develop their knowledge and understanding of the ways in which scientific ideas change through time and how the nature of these ideas and the uses to which they are put are affected by the social, moral, spiritual, and cultural contexts in which they are developed; in doing so, they should begin to recognise that while science is an important way of thinking about experience, it is not the only way.

\section{Level Statements of Attainment}

Pupils should:

4 Be able to give an account of some scientific advance, for example, in the context of medicine, agriculture, industry or engineering, describing the new ideas and investigation or invention and the life and times of the principal scientist involved.

5 Be able to discuss clearly with others their way of thinking about some experiment which is new to them.

Be able to demonstrate that different interpretations of the experimental evidence that they have collected are possible.

6 Be able to use one or two explanatory models from their own learning in science to demonstrate how predictions have been made which stimulate new experiments.

Be able to describe and explain one incident from the history of science where successfil predictions were made to establish a new model for example, the work of scientists on:

- air-borne organisms (Pasteur)

- the evidence for atmospheric pressure (Pascal)

7 Be able to give an historical account of a change in accepted theory or explanation, and demonstrate an understanding of its effects on people's lives -physically, socially, spiritually and morally, for example, understanding the ecological balance and greater concern for our environment; the observations of the motion of Jupiter's moons and Galileo's dispute with the Church.

Be able to demonstrate an appreciation of differing functions of scientific evidence and imaginative thought in carrying forward scientific understanding, for example, discovery of structure of DNA - the different approach of Franktin from that of Watson and Crick.

8 Be able to explain how a scientific explanation from a different culture or a different time contributes to our present understanding. Understand the uses of evidence and the tentative nature of proof.

9 Be able to distinguish between generalizations and predictive theories and give an example of each, for example, such pairs might be: 'all metals conduct electricity' and 'the theory of a free electron gas which predicts this property', OR 'a clear sky in winter always means frost at night' and 'the absence of clouds to reflect back the Earth's radiation os the basis of such a prediction'.

10 Be able to demonstrate an understanding of the differences in scientific opinion in some topic, either from the past or the present, drawn from studying the relevant literature, for example, plate tectonics and the wrinkling of a shrinking Earth $O R$ living things produce their own kind and the spontaneous generation of species.

Be able to relate differences of scientific opinion to the uncertain nature of scientific evidence, for example, what is the cause of 'cot deaths', OR what is responsible for the death of trees in European forests? 